\title{
Antioxidant and Anti-inflammatory Effects of Ginseng Berry Ethanol Extracts as a Cosmetic Ingredient
}

Hyeon-Suk Kim, Kyoung-Sook Ko*

Department of Beauty Design, Wonkwang University, Iksan-si, Jeollabuk-do, Korea

\author{
*Corresponding author: Kyoung-Sook Ko, \\ Department of Beauty Design, Wonkwang \\ University, 460 Iksandae-ro, Iksan-si, \\ Jeollabuk-do 54538, Korea \\ Tel.: +82638506649 \\ Fax: +82638506666 \\ Email: koks31@wku.ac.kr
}

\section{Received July 08, 2020}

Revised September 08, 2020

Accepted September 10, 2020

Published September 30, 2020

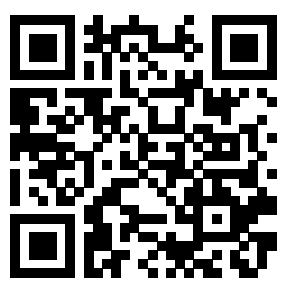

\begin{abstract}
Purpose: This study was conducted to evaluate the applicability of ginseng berry in cosmetics. Methods: Ethanol extract of ginseng berry was analyzed using gas chromatography-mass spectrometry (GC-MS). 2,2-Diphenyl-1-picrylhydrazyl (DPPH) scavenging was used to determine the antioxidant activity, total polyphenol, and flavonoid content. Cell viability (MTT assay) confirmation was conducted to determine the toxicity, while the anti-inflammatory effect was investigated by measuring the inhibition of nitric oxide (NO) production. Results: The total polyphenol and flavonoid contents were $152 \pm 12.4 \mu \mathrm{g} / \mathrm{mL}$ and $50.16 \pm 1.48 \mu \mathrm{g} / \mathrm{mL}$, respectively. DPPH scavenging activity in the extract with a concentration of 0.25 $\mathrm{mg} / \mathrm{mL}$ increased to $59.21 \pm 4.20 \%, 0.5 \mathrm{mg} / \mathrm{mL}$ to $69.27 \pm 2.38 \%$, and $1 \mathrm{mg} / \mathrm{mL}$ to $89.30 \pm 1.25 \%$. Cell viability evaluation showed a survival rate of $80.92 \pm 5.77 \%$ for $1 \mathrm{mg} / \mathrm{mL}$ concentration range for cell viability evaluation $-0.125-1 \mathrm{mg} / \mathrm{mL}$. The inhibitory effect of nitric oxide (NO) production through RAW 264.7 cells induced by inflammatory response with lipopolysaccharide (LPS) resulted in an extract concentration of $25.58 \pm 3.11 \mu \mathrm{M}(0.25 \mathrm{mg} / \mathrm{mL}), 13.91 \pm 3.86 \mu \mathrm{M}(0.5 \mathrm{mg} / \mathrm{mL})$, and $3.91 \pm 1.55 \mu \mathrm{M}(1 \mathrm{mg} / \mathrm{mL})$. The increase in concentration confirms an antiinflammatory effect. Conclusion: Ethanol extract of ginseng berry has excellent antioxidant and anti-inflammatory effects and can be a functional cosmetic material.
\end{abstract}

Keywords: Ginseng berry, Antioxidant, Anti-inflammation, Polyphenol, Cosmetics

\section{Introduction}

최근 화장품 유해성분에 대한 위험성 문제와 친환경적인 제품 을 선호하는 소비자로 인해 천연 화장품 시장이 세계적으로 증가하 고 있다. 국내에서도 천연화장품 개발이 꾸준히 증가 추세에 있으며 국내산 천연화장품 소재의 효능(Kim et al., 2018; Hwang et al., 2020)이 검증되어 다양한 제품으로 출시되고 있다. 특히 해외에서 한국 화장품의 구매가 증가하면서 해외 소비자에게 인지도가 높은 국내산 천연물을 소재로 한 화장품 연구도 활발히 진행되고 있다.

한국을 대표하는 약리성분을 함유한 약재 중 인삼 (Panax ginseng C.A. meyer)은 약, 건강식품, 뿐만 아니라 화장품으 로도 만들어지고 있다. Park (1996)의 연구에서 1957년 소련 의 Brekhman에 의해 사포닌 배당체가 약효성분임이 밝혀졌고, 1960-1980년대 일본의 Shibata(Shibata et al., 1966), Tanaka (Matsuura et al., 1984) 그룹에 의해 인삼 사포닌(3-6\%)의 성분이
Dammarane-Saponin으로 확인되었다.

오가피과인 인삼은 약효 성분으로 알려진 ginsenoside가 인삼 뿌 리뿐 아니라 잎(Lee et al., 2015)과 열매에도 다양하게 존재하고 있 음이 많은 연구를 통해 밝혀지고 있다. Jeon et al., 2011의 연구에 서 유산균으로 발효시킨 후 인삼열매 추출물에서는 항산화 활성이 높고 피부 주름 및 염증 예방에 효과적으로 활용 가능한 소재가 될 수 있을 것이라는 보고도 있었다. 진세노이드의 일부 성분의 경우, 뿌리보다 열매에 더 많은 함량을 지니고 있는 것으로 확인되었다.

인삼열매에는 항당뇨 효과, 항암효과, 항알러지 효과 등이 있는 것으로 알려져 있으며그에 따른 연구도 진행되어지고 있다. 또한 인 삼 열매 추출물은 자외선을 원인으로 하는 광노화와 세포 활성이 떨 어지는 자연 노화에 적용 가능한 소재가 될 수 있을 것이며 피부노 화를 지연하고 개선시킬 수 있는 새로운 한방 소재로도 활용(Yeom et al., 2010) 가능하다. 그러나 현재는 그에 대한 연구가 아직 미비 한 상황이다. 
따라서 본 연구에서는 인삼근에 집중되어 왔던 연구에서 인삼의 부산물인 인삼열매를 화장품 소재로 활용할 수 있도록 인삼열매의 항산화(Song et al., 2014), 항독성, 항염 효과 등을 평가하고 연구 문헌을 고찰하여 그 가능성을 검토하고자 한다.

\section{Methods}

\section{1. 실험재료}

1) 시약 및 기기

본 연구에 사용된 시약은 2,2-diphenyl-1-picrylhydrazyl (DPPH), butylated hydroxytoluene (BHT), dimethyl sulfoxide (DMSO), ascorbic acid, lipopolysaccharide (LPS), 3-(4,5-dimethylthiazol-2-yl)-2,5-diphenyl tetrazolium bromide (MTT)는 Sigma Aldrich (USA)에서 구입하여 사용하 였다. Gas Chromatograph-Mass Spectrometry (GC-MS, QP-2010; Ultra, Shimadzu co., Japan), UV/VIS 분광 광도계 (UV-2450; Shimadzu Co.), Microplate reader (BioTek, US), $\mathrm{CO}_{2}$ incubator, Rotary Evaporator (EYELA N-1110; Tokyo Rikakikai, Japan) 를 사용하였다.

\section{2) 추출물 제조}

본 실험에 사용한 인삼열매는 강원도 정선군에서 재배되어 정 선군 농업기술센터에서 분말 제조하여 판매되는 것을 구입하여 사 용하였다. 건조된 인삼열매 분말 $10 \%$ 을 $70 \%$ 에탄올 수용액에 침 지 시키고, 초음파추출법을 이용하여 $25^{\circ} \mathrm{C}$ 에서 추출시간을 $6 \mathrm{~h}$ 으로 하여 인삼열매의 유효성분을 추출하였다. 추출물을 $4{ }^{\circ} \mathrm{C}$ 에 서 원심분리기(CS150NX; Hitachi Ltd., Japan) 4000 rpm으 로 $20 \mathrm{~min}$ 작동시키고, 분리한 상층액을 공극이 $0.22 \mu \mathrm{m}$ 인 멤 브레인(ADVANTEC Co. Ltd, Japan)으로 여과한 후 감압 농축 (Evaporator; Tokyo Rikakikai co. Ltd., Japan)하고, 완전이 동 결 건조하여 최종적인 인삼열매 초음파 추출물 분말을 제조하였으 며, 분석시료로 사용하였다.

\section{3) 총 폴리페놀 함량}

농도별로 제조한 인삼열매 초음파 추출물을 $1 \mathrm{mg} / \mathrm{mL}$ 농도로 제조한 용액에 folin-ciocalteau's phenol reagent $1 \mathrm{~mL}$ 를 가하고 암실에서 $5 \mathrm{~min}$ 간 반응시킨 뒤에 $10 \%$ 탄산 소듐 $\left(\mathrm{Na}_{2} \mathrm{CO}_{3}\right) 1 \mathrm{~mL}$ 을 넣고 실온에서 $1 \mathrm{~h}$ 반응시킨 후 UV/VIS 분광 광도계(UV-2450;
Shimadzu Co., Japan)로 $700 \mathrm{~nm}$ 에서 흡광도를 측정하였다. 이 때, gallic acid (GA; Sigma-Aldrich)는 0-200 $\mu \mathrm{g} / \mathrm{mL}$ 의 농도로 제조하여 시료와 동일한 방법으로 분석한 뒤 얻은 표준 검량선으로 추출물의 총 페놀 함량을 산출하였으며, gallic acid equivalents (mg GAE/g extract)로 나타내었다.

\section{4) 총 플라보노이드 함량}

에탄올 농도별로 제조한 인삼열매 초음파 추출물을 $200 \mu \mathrm{g} /$ $\mathrm{mL}$ 농도로 제조한 용액에 di-ethylene glycol (Sigma-Aldrich) $2 \mathrm{~mL}, 1 \mathrm{~N} \mathrm{NaOH}$ (Sigma-Aldrich) $0.02 \mathrm{~mL}$ 를 첨가한 다음 $37^{\circ} \mathrm{C}$ 항온수조에서 $1 \mathrm{~h}$ 동안 둔 후 UV/VIS 분광광도계(UV-2450; Shimadzu Co.)로 $420 \mathrm{~nm}$ 에서 흡광도를 측정하였다. 이때 총 플 라보노이드 함량은 루틴(Sigma-Aldrich)을 표준물질로 사용하여 보정곡선을 작성하고 그것으로부터 총 플라보노이드 함량을 구하 였다.

\section{2. 성분 분석(GC/MS)}

인삼열매의 에탄올 추출물의 성분 분석을 위해 $\mathrm{GC}-\mathrm{MS}$ 장 비(QP-2010 Ultra; Shimadzu Co.)를 이용하였으며 추출물을 $\mathrm{DMSO}$ 에 교반 한 후, 원심분리기를 사용하여 부유물을 제거한 뒤 마이크로 필터(ADVANTEC Co Ltd, Japan) $0.45 \mu \mathrm{m}$ 로 여과하 였다. Column 은 Elite- $5 \mathrm{~ms}(30 \mathrm{~m} \times 0.25 \mathrm{~mm} \mathrm{I.D,} 0.25 \mu \mathrm{m}$ film thickness), Carrier gas는 He $1.0 \mathrm{~mL} / \mathrm{min}$, Injection temp $250^{\circ} \mathrm{C}$, Split ratio (10:1), GC oven temp. program $50-300^{\circ} \mathrm{C}$ $/ 3^{\circ} \mathrm{C} / \mathrm{min}$, injection volume은 $1.0 \mathrm{~mL}$, MS Ion source temp. $220^{\circ} \mathrm{C}$, MS Interface temp., $250^{\circ} \mathrm{C}$ 조건으로 성분을 분석하였다.

\section{3. 인삼열매 에탄올 추출물의 항산화 측정 (DPPH radical scavenging activity)}

인삼열매의 항산화 측정실험은 시료 $2 \mathrm{~mL}$ 에 $0.2 \mathrm{mM}$ 의 $\mathrm{DPPH} 1 \mathrm{~mL}$ 를 넣고 교반 한 후 $37^{\circ} \mathrm{C}, 30 \mathrm{~min}$ 반응 후 spectrophotometer, $517 \mathrm{~nm}$ 에서 흡광도를 측정하였다. 대조군은 $1 \mathrm{mg} / \mathrm{mL}$ 의 ascorbic acid를 사용하였고, DPPH radical 소거활성 은 다음과 같이 계산하였다.

DPPH radical scavenging activity $(\%)=[1-(\mathrm{B} / \mathrm{A})] \times 100$

$\mathrm{A}$ : 대조군의 흡광도( $\mathrm{DPPH}$ 용액), $\mathrm{B}$ : 샘플 자체 흡광도

\section{4. 세포독성 시험(MTT assay)}

소재의 안정성 시험으로 세포독성시험인 MTT assay를 사용하

Table 1. Total polyphenol and flavonoid contents of $\mathbf{7 0} \%$ ethanol extracts of ginseng berry by ultrasonication

\begin{tabular}{lcc}
\hline & Total polyphenol contents (GAE mg/g) & Total flavonoid contents (TA/100g) \\
\hline Minseng berry & $152 \pm 12.4$ & $50.16 \pm 1.48$ \\
\hline
\end{tabular}


였다. 세포독성 시험에 사용한 세포는 대식세포인 RAW 264.7 cell (한국 세포주 은행 생물자원센터, 한국)을 사용하였다. Raw 264.7 cell을 96 well plate $1 \times 10^{4} \mathrm{cell} / \mathrm{mL}$ 씩 분주하여 $24 \mathrm{~h}$ 배양 후 희 석한 추출물을 각 well에 처치하여 $24 \mathrm{~h}$ 동안 배양하였다. 세포 병
변을 확인한 후 배양액 $100 \mu \mathrm{L}$ 씩을 제거한 후, MTT 용액 $10 \mathrm{uL}$ 씩을 각 well에 가하여 $5 \% \mathrm{CO}_{2}, 37^{\circ} \mathrm{C}$ 배양기에서 $4 \mathrm{~h}$ 동안 정치 하였다. MTT용액을 완전히 제거하여 배양 plate를 건조한 후 200 $\mathrm{uL}$ dimethyl sulfoxide (DMSO; Sigma-Aldrich)로 세포 내에 형

Table 2. Chemical composition of ethanol extract of Ginseng berry using GC-MS analysis

\begin{tabular}{|c|c|c|c|}
\hline Peak & Compound name & Time (min) & Content (\%) \\
\hline \multicolumn{4}{|c|}{ Solvent } \\
\hline 1 & Mequinol & 15.187 & 0.97 \\
\hline 2 & 2(3H)-Furanone, dihydro-4-hydroxy- & 15.389 & 3.06 \\
\hline 3 & (S)-(-)-2-Chloropropionic acid & 15.834 & 1.80 \\
\hline 4 & Glyceraldehyde & 16.558 & 4.47 \\
\hline 5 & 1,3-Dioxolane, 2,4,5-trimethyl- & 16.957 & 1.84 \\
\hline 6 & 2(3H)-Furanone, dihydro-4-hydroxy- & 17.268 & 2.04 \\
\hline 7 & Aziridine, 2-methyl-3-(1-methylethyl)-, trans- & 17.928 & 1.15 \\
\hline 8 & 4-Methoxycarbonyl-4-butanolide & 18.403 & 0.95 \\
\hline 9 & Catechol & 18.653 & 3.40 \\
\hline 10 & Methyl salicylate & 18.808 & 2.61 \\
\hline 11 & 2,4(1H,3H)-Pyrimidinedione, 5-hydroxy- & 19.015 & 1.05 \\
\hline 12 & 1,4:3,6-Dianhydro-.alpha.-d-glucopyranose & 19.469 & 1.85 \\
\hline 13 & Benzofuran, 2,3-dihydro- & 19.634 & 7.99 \\
\hline 14 & 5-Hydroxymethylfurfural & 19.875 & 1.14 \\
\hline 15 & 1,2,3-Propanetriol, 1-acetate & 20.511 & 1.57 \\
\hline 16 & Benzene, 1,3-bis(1,1-dimethylethyl)- & 20.696 & 0.99 \\
\hline 17 & 1H-Tetrazol-5-amine & 21.383 & 0.85 \\
\hline 18 & 6-Aminotetrazolo(b)pyridazine & 21.730 & 0.47 \\
\hline 19 & 4-Methyltetrahydro-1,3-oxazine-2-thione & 21.854 & 0.39 \\
\hline 20 & Sulfurous acid, hexyl octyl ester & 21.961 & 0.94 \\
\hline 21 & m-Aminophenylacetylene & 22.674 & 0.65 \\
\hline 22 & 2-Methoxy-4-vinylphenol & 23.476 & 2.84 \\
\hline 23 & Benzaldehyde, 3-hydroxy- & 25.504 & 0.97 \\
\hline 24 & Tridecane, 1-iodo- & 27.426 & 1.85 \\
\hline 25 & Sucrose & 28.339 & 7.30 \\
\hline 26 & (3-Nitrophenyl) methanol, n-propyl ether & 28.739 & 1.19 \\
\hline 27 & beta.-D-Glucopyranose, 1,6-anhydro- & 30.573 & 1.09 \\
\hline 28 & Octadecane, 6-methyl- & 31.060 & 1.05 \\
\hline 29 & Phenol, 2,4-bis(1,1-dimethylethyl)- & 31.720 & 2.91 \\
\hline 30 & 3',5'-Dimethoxyacetophenone & 33.721 & 1.53 \\
\hline 31 & Decanal & 34.220 & 2.88 \\
\hline 32 & Diethyl phthalate & 34.833 & 1.78 \\
\hline 33 & Hexanoic acid, 2-ethylhexyl ester & 35.263 & 7.51 \\
\hline 34 & 4-Hydroxy-2-methoxycinnamaldehyde & 39.986 & 0.89 \\
\hline 35 & 4-((1E)-3-Hydroxy-1-propenyl)-2-methoxyphenol & 40.176 & 4.36 \\
\hline 36 & Pyrrolo[1,2-a]pyrazine-1,4-dione, hexahydro- & 40.678 & 2.01 \\
\hline 37 & n-Decanoic acid & 48.095 & 1.99 \\
\hline 38 & Benzenepropanoic acid, 2,5-dimethoxy- & 48.691 & 1.06 \\
\hline 39 & Dodecanoic acid, 3-hydroxy- & 53.308 & 0.77 \\
\hline 40 & 5-Pyrrolidino-2-pyrrolidone & 55.979 & 1.58 \\
\hline 41 & Hexadecanoic acid, 2-hydroxy-1-(hydroxymethyl)ethyl ester & 63.785 & 1.31 \\
\hline 42 & Z,Z-8,10-Hexadecadien-1-ol & 68.190 & 1.75 \\
\hline 43 & Octadecanoic acid, 2-hydroxy-1-hydroxymethyl)ethylester & 68.974 & 6.70 \\
\hline 44 & Stigmasterol & 80.350 & 1.09 \\
\hline \multirow[t]{2}{*}{45} & .gamma.-Sitosterol & 81.606 & 3.41 \\
\hline & & 85 & 100 \\
\hline
\end{tabular}

Content $(\%)=$ peak area of each compound/peak area of the internal standard $\times 100$.

GC-MS: gas chromatograph-mass spectrometry. 


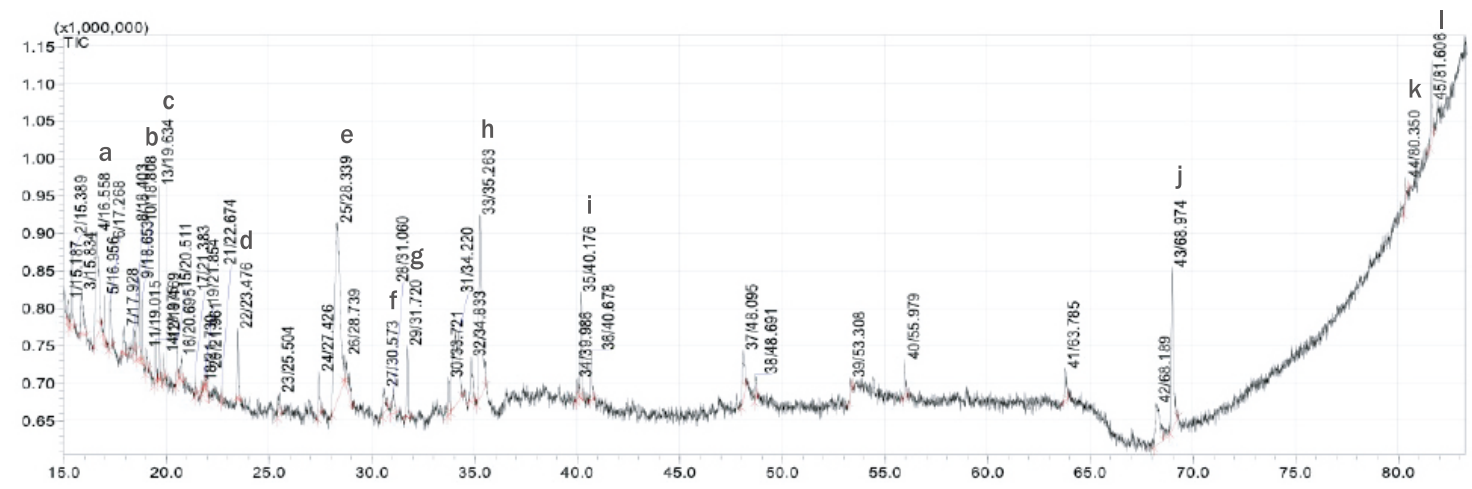

Figure 1. GC-MS graph of ethanol extract of ginseng berry.

Bioactive compounds were identified in 70\% ethanol extracts of ginseng berry. Comparison of standard computer software data (GC-MS system data) and spectrum: a, glyceraldehyde (4.47\%); b, catechol (3.4\%); c, benzofuran, 2,3-dihydro-(7.99\%); d, 2-Methoxy-4-vinylphenol (2.84\%); e, sucrose (7.3\%); f, beta-D-glucopyranose (1.09\%); g, phenol (2.91\%); h, hexanoic acid (1.31\%); I, methoxyphenol (4.36\%); j, octadecanoic acid (6.7\%); k, stigmasterol (1.09\%); I, gamma-sitosterol (3.41\%), GS-MS, gas chromatography-mass spectrometry.

성된 formazan 결정체를 용해하여 ELISA plate reader (BioTec $\mathrm{Ex} 800, \mathrm{USA})$ 로 $570 \mathrm{~nm}$ 에서 흡광도를 측정하였다. 세포생존율 (cell viability)은 다음과 같은 식으로 계산되었다.

Cell viability $(\%)=[($ Exp. - Blank $) /$ Control $] \times 100$

\section{5. 항염증 평가(NO assay)}

항염증 평가는 lipopolysaccharide (LPS)에 의해 유도된 nitric oxide (NO)생성억제 활성을 측정하였다. 항염증 실험에는 면 역세포를 사용해야 하므로 대식세포인 Raw 264.7 cell (mouse monocyte macrophage)을 한국 세포주 은행 생물자원센터에서 분 양 받아서 사용하였다.

Raw 264.7 cell을 $3 \times 10^{4} \mathrm{cell} / \mathrm{mL}$ 씩 분주하여 $24 \mathrm{~h}$ 배양하였 다. 희석한 추출물을 각 well에 처리하고 동시에 LPS $1 \mu \mathrm{L} / \mathrm{mL}$ 를 처리하여 $24 \mathrm{~h}$ 동안 재배양하였다

RAW 264.7 cell에서 생성된 NO의 양을 griess 시약을 사용하 여 측정하였다. 세포배양 상등액 $100 \mu \mathrm{L}$ 와 griess시약 $100 \mu \mathrm{L}$ 을 혼합 후 실온에서 $10 \mathrm{~min}$ 반응시킨 뒤에 $540 \mathrm{~nm}$ 에서 Microplate reader (BioTek, US)로 흡광도를 측정하였다. 표준곡선은 $\mathrm{NaNO}_{2}$ 를 적정하여 작성하였다.

\section{6. 통계처리}

통계처리 실험결과는 3 회 반복해서 실시하였고, 통계분석 데이 터는 평균 \pm 표준편차(Mean \pm Standard Deviation. $\mathrm{SD}$ )로 표현하 였다. 데이터의 통계처리을 위해 Statistical Package for Social Science (SPSS; USA)를 이용하여 분석하였으며, Student's $t$-test로 $\mathrm{p}$ value가 0.05 미만일 경우에 통계적으로 유의한 것으 로 판정하였다. $\left({ }^{*} p<0.05,{ }^{* *} p<0.01\right)$

\section{Results and Discussion}

\section{1. 총 폴리페놀 및 플라보노이드 함량}

천연 식물의 추출물에 다량 존재하는 폴리페놀과 폴라보노이드는 항산화 성분을 다량 함유하고 있다(Ko, 2012). 본 연구에서는 인삼 열매를 $70 \%$ 에탄올 추출물에 존재하는 총 폴리페놀과 플라보노이드 함량을 측정하였다. 인삼열매 에탄올 추출물의 함량측정 결과 총 폴 리페놀은 $152 \pm 12.4 \mu \mathrm{g} / \mathrm{mL}$, 총 플라보노이드는 $50.16 \pm 1.48 \mu \mathrm{g} /$ $\mathrm{mL}$ 로 나타났다(Table 1).

\section{2. 성분 분석(GC/MS)}

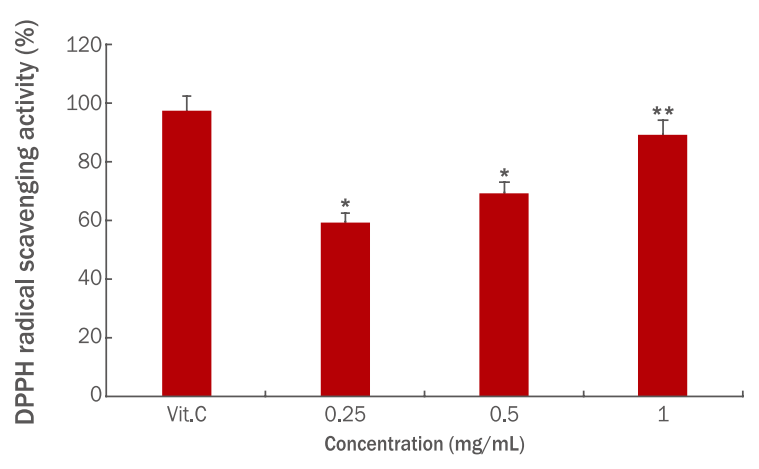

Figure 2. DPPH radical scavenging activity of ethanol extract of ginseng berry.

DPPH radical scavenging analysis was performed to investigate the antioxidant effects of ethanol extract of ginseng berry at varying concentrations of $0.25,0.5$, and $1 \mathrm{mg} / \mathrm{mL}$. EE, $70 \%$ ethanol extracts; Vit C, ascorbic acid;. Each value is represented as $M \pm S D(n=3)$. Statistically significant differences are marked with an asterisk $\left({ }^{*} p<0.05,{ }^{* *} p<0.01\right)$; DPPH, 1,1-diphenyl-2picrylhydrazyl; $\mathrm{M} \pm \mathrm{SD}$, mean \pm standard deviation. 


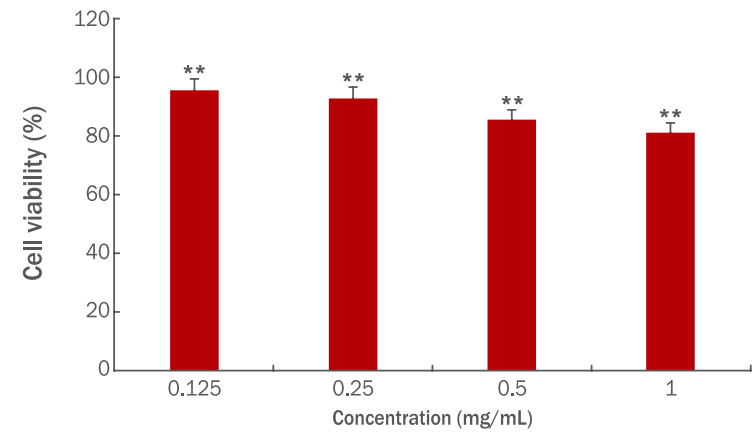

Figure 3. Cytotoxicity of ethanol extracts of ginseng berry in RAW 264.7 cells using MTT assay.

RAW 264.7 cells were incubated with $70 \%$ ethanol extracts of ginseng berry at varying concentrations of $0.125,0.25,0.5$, and $1 \mathrm{mg} / \mathrm{mL}$. Absorbance was measured at $570 \mathrm{~nm}$. Results are represented as $\mathrm{M} \pm \mathrm{SD}$ of three independent experiments. Statistically significant differences are marked with an asterisk $\left({ }^{* *} p<0.01\right)$. MTT, 3-(4,5-dimethylthiazol2-yl)-2,5-diphenyl tetrazolium bromide; $\mathrm{M} \pm \mathrm{SD}$, mean \pm standard deviation.

인삼열매 에탄올 추출물을 GC-MS로 성분을 분석한 결과(Table 2) 다량의 산류(22.08\%)와 알코올류, 알데히드류(decanal $2.88 \%$, benzaldehyde $0.97 \%$ ), 에스테르류(methyl salicylate, 2.61\%)등 45 종의 성분이 검출되었다.

본 연구에서 Table 2와 Figure 1의 결과와 같이 화장품 생 산에 사용 가능한 올레산 혼합물인 octadecanoic acid (stearic acid, 6.7\%)와 hexadecanoic acid(1.31\%), 다당류(sucrose 7.3\%, glyceraldehyde $4.47 \%$, beta-D-glucopyranose1.09\%), 페놀 화합 물(phenol $2.91 \%$, vinylphenol $2.84 \%$, methoxyphenol $4.36 \%$ )등 이 추출된 것을 확인하였다. 또한 benzofuran이 $7.99 \%$ 추출되었는 데 벤조퓨란 화합물은 항 종양, 항균, 항산화 및 항 바이러스 활성과 같은 강력한 생물학적 활성을 가지고 있어 화학 및 제약 연구에서도 관심을 갖고 있는 천연 화합물이다(Miao et al., 2019).

항노화 효과가 있는 항산화 생리활성 성분인 stigmasterol (1.09\%)과 .gamma.-sitosterol (3.41\%), catechol (3.4\%)이 확인 되었고, 항염(암세포 증식 억제)과 지방 축적 억제 생리활성 성분인 pyrrolidone (1.58\%)과 같은 알칼로이드 성분은 고려홍삼(Hyun et al., 2020) 연구에서도 확인된 바 있다. 인삼열매 성분은 항산화, 항 염(Lee et al., 2014) 효과가 있는 유효 성분을 다량 함유하고 있으 므로 노화 방지 기능성 화장품의 소재로서의 가능성이 있음을 확인 하였다.

\section{DPPH free radical 소거능}

$\mathrm{DPPH}$ 측정법은 활성산소의 제거능을 알아보는 방법으로 Figure 2 와 같이 양성대조군인 ascorbic acid $(100 \mu \mathrm{M})$ 를 처리한 군에 는 $97.2 \pm 0.12 \%$ 의 소거능을 보였으며, 인삼열매 에탄올 추출물은

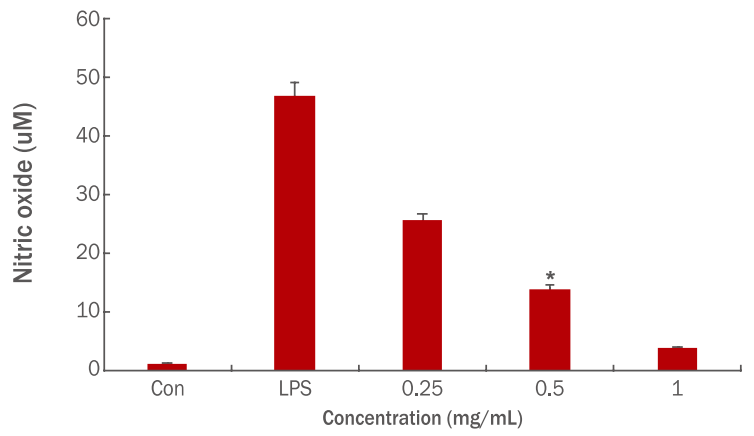

Figure 4. Effects of ethanol extract of ginseng berry on NO production levels in LPS-induced RAW 264.7 cells.

RAW 264.7 cells were treated with various concentrations of $70 \%$ ethanol extracts of ginseng berry for $2 \mathrm{~h}$, followed by LPS ( 1 $\mu \mathrm{g} / \mathrm{mL}$ ) for $24 \mathrm{~h}$. The amount of NO was measured using Griess assay. Results are represented as $\mathrm{M} \pm \mathrm{SD}$ of three independent experiments. Statistically significant differences are marked with an asterisk ( $\left.{ }^{*} p<0.05\right)$. NO, nitric oxide; LPS, lipopolysaccharide; $\mathrm{M} \pm \mathrm{SD}$, mean \pm standard deviation.

$0.25 \mathrm{mg} / \mathrm{mL}$ 에서 $59.21 \pm 4.20 \%, 0.5 \mathrm{mg} / \mathrm{mL}$ 에서 $69.27 \pm 2.38 \%$, $1 \mathrm{mg} / \mathrm{mL}$ 에서 $89.30 \pm 1.25 \%$ 로 농도가 증가함에 따라서 소거능도 증가함을 확인하였다. 이러한 높은 소거능은 10 년, 15 년 산 산양삼 의 $\mathrm{DPPH}$ radical 소거능이 각각 $72.24 \pm 1.19,80.17 \pm 1.64 \%$ 로 나 타난 것과 비슷한 결과이다(Lee et al., 2018). 이것은 인삼열매 추 출물이 피부노화를 방지하는 항산화 효과가 우수함을 나타내고 있 다(Figure 2).

\section{4. 세포독성 시험(MTT assay)}

인삼열매 추출물의 세포독성 시험결과를 Figure 3에 나타냈다. 0.125-1 mg/mL의 농도범위까지 평가하였을 때, 세포독성은 각 농도에서 모두 $80 \%$ 이상의 생존율을 관찰하였으며 최고 농도인 1 $\mathrm{mg} / \mathrm{mL}$ 에서 $80.92 \pm 5.77 \%$ 의 생존율을 확인하였다. 인삼열매의 또 다른 연구(Jeon et al., 2011)에서 인삼열매 추출물과 유산균 발효 인삼열매 추출물에서 $0.50 \%$ 이하의 농도에서 독성이 전혀 없으며, $1.00 \%$ 이상에서는 세포생존율이 약간 감소하였다는 결과보다는 낮 은 생존율이지만 독성이 강하지 않은 안전한 소재임을 확인하였다.

\section{5. 항염증 평가(NO assay)}

LPS에 의해 유도된 nitrite oxide (NO)의 생성 억제 활성을 측정 한 결과, 대조군의 경우 $1.2 \mu \mathrm{M}$ 이었다. LPS에 의해 $46.83 \mu \mathrm{M}$ 농도 로 생성된 NO가 인삼열매 추출물의 농도 $0.25 \mathrm{mg} / \mathrm{mL}$ 에서 25.58 $\pm 3.11 \mu \mathrm{M}$ 로 염증유발 물질을 $45.36 \%$ 감소시켰으며, $0.5 \mathrm{mg} / \mathrm{mL}$ 일 때 $13.91 \pm 3.86 \mu \mathrm{M}(70.28 \%), 1 \mathrm{mg} / \mathrm{mL}$ 일 때 $3.91 \pm 1.55 \mu \mathrm{M}$ (91.63\%) 저하시켜 농도가 증가함에 따라 Figure 4 와 같이 농도 의 존적으로 $\mathrm{NO}$ 생성량이 감소하였다. 따라서 인삼열매 추출물이 염증 
을 완화시키는 항염증 효과가 있는 것으로 확인되었다.

\section{Conclusion}

본 연구에서는 인삼열매 에탄올 추출물의 화장품 소재로서의 항 산화, 항염 효과를 알아보기 위해 성분분석과 총 폴리페놀과 플라보 노이드 함량을 알아보았다. 또한 항산화 활성을 $\mathrm{DPPH}$ free radical 소거능을 통해 확인하고, 세포 생존률 평가와 항염증 평가를 실시하 였다.

그 결과 인삼열매 총 폴리페놀 함량은 $152 \pm 12.4 \mu \mathrm{g} / \mathrm{mL}$, 총 플 라보노이드 함량은 $50.16 \pm 1.48 \mu \mathrm{g} / \mathrm{mL}$ 로 나타났다. $\mathrm{DPPH}$ free radical 소거능은 인삼열매 에탄올 추출물 $0.25 \mathrm{mg} / \mathrm{mL}$ 에서 59.21 $\pm 4.20 \%, 0.5 \mathrm{mg} / \mathrm{mL}$ 에서 $69.27 \pm 2.38 \%, 1 \mathrm{mg} / \mathrm{mL}$ 에서 $89.30 \pm$ $1.25 \%$ 로 농도가 증가함에 따라서 라디컬 소거능도 함께 증가함을 확인하였다. 세포 생존률 평가 결과에서는 세포 생존률이 0.125-1 $\mathrm{mg} / \mathrm{mL}$ 의 농도범위까지 평가하였을 때, 최고 농도인 $1 \mathrm{mg} / \mathrm{mL}$ 에서 $80.92 \pm 5.77 \%$ 의 생존률을 확인하여 각 농도에서 모두 $80 \%$ 이상의 생존률을 관찰하였다. 또한 항염증 평가를 위한 $\mathrm{NO}$ assay에서 인 삼열매 추출물의 농도가 $0.25 \mathrm{mg} / \mathrm{mL}$ 일 때 $25.58 \pm 3.11 \mu \mathrm{M}, 0.5$ $\mathrm{mg} / \mathrm{mL}$ 일 때 $13.91 \pm 3.86 \mu \mathrm{M}, 1 \mathrm{mg} / \mathrm{mL}$ 일 때 $3.91 \pm 1.55 \mu \mathrm{M}$ 로 농도가 증가함에 따라 농도 의존적으로 $\mathrm{NO}$ 생성량이 감소하였음을 확인하였다.

이를 통해 인삼열매 추출물이 화장품 소재로서 항산화, 항염 효 과가 있는 독성이 없는 안전한 소재로 평가되었다. 더불어 뛰어난 항산화 활성과 피부 주름 및 염증 예방에 적용 가능한 소재(Jeon et al., 2011)로서의 연구도 계속된다면 한국을 대표할 수 있는 천연 기 능성 화장품 소재로 활용 가능할 것으로 사료된다.

\section{Author's contribution}

HSK and KSK made equal contributions to this work. HSK and KSK designed all experimental investigations. HSK contributed to some aspects of the analysis and wrote the manuscript. KSK oversaw the project. HSK and KSK read and approved the final version of the manuscript.

\section{Author details}

Hyeon-suk Kim (Lecturer), Department of Beauty Design, Wonkwang University, 460 Iksan-daero, Iksan-si, Jeollabuk-do 54538, Korea; Kyoung-suk Ko (Professor), Department of Beauty Design, Wonkwang University, 460 Iksan-daero, Iksan-si, Jeollabuk-do 54538, Korea.

\section{References}

Hwang JU, Yang YH, Choe TB. Physiological characteristics of germinated oat (Avena sativa) extract as raw material for cosmetics. Asian Journal of Beauty and Cosmetology, 18: 137-148, 2020.

Hyun SH, Kim SW, Seo HW, Youn SH, Kyung JS, Lee YY, In G, Park CK, Han CK. Physiological and pharmacological features of the non-saponin components in Korean red ginseng. Journal of Ginseng Research, 44: 527-537, 2020.

Jeon JM, Choi SK, Kim YJ, Jang SJ, Cheon JW, Lee HS. Antioxidant and antiaging effect of ginseng berry extract fermented by lactic acid bacteria. Journal of the Society of Cosmetic Scientists of Korea, 37: 75-81, 2011.

Kim GW, Choi YH, Kim BL, Kim YU, Seong RS, Han MH, Kim GA, Choi MJ, Jeong YG. Determination of anti-oxidative and whitening effects of complex extracts obtained from sprout Panax ginseng C.A. Meyer and Cassia nomame (Sieb.) Honda on skin. Asian Journal of Beauty and Cosmetology, 16: 309-320, 2018.

Ko KS. A study on antioxidant effect of methanol extract from Viola mandshurica. Journal of the Korean Society of Cosmetology, 18: 1082-1086, 2012.

Lee JH, Cho SH, Yun MY, An Sk, Jang HH, Lee SN, Song GY. Anti-wrinkle effect of rare ginsenosides, produced from ginsenoside Rd. Asian Journal of Beauty and Cosmetology, 13: 909-916, 2015.

Lee KS, Kim GH, Seong BJ, Kim SI, Han SH, Lee SS, Yang H, Yoo YC. Anti-inflammatory activity of solvent fractions from ginseng berry extract in LPS-induced RAW264.7 cells. Korean Journal of Medicinal Crop Science, 22: 449-456, 2014.

Lee SW, Choi HI, Kim AJ, Han JS. Applicability of Sunsik with cultivated wild ginseng powder as a beauty food. Asian Journal of Beauty and Cosmetology, 16: 201-210, 2018.

Matsuura H, Kasai R, Tanaka O, Saruwatari Y, Kunihiro K, Fuwa T. Further studies on dammarane-saponins of ginseng roots. Chemical and Pharmaceutical Bulletin, 32: 1188-1192, 1984.

Miao YH, Hu YH, Yang J, Liu T, Sun J, Wang XJ. Natural source, bioactivity and synthesis of benzofuran derivatives. RSC Advances, 47: 27510-27540, 2019. 
Park JD. Recent studies on the chemical constituents of Korean ginseng (Panax ginseng C.A. Meyer). Journal of Ginseng Research, 20: 389-415, 1996.

Shibata S, Tanaka O, Ando T, Sado M, Tsushima S, Ohsawa T. Chemical studies on oriental plant drugs. XIV. protopanaxadiol, a genuine sapogenin of ginseng saponins. Chemical and Pharmaceutical Bulletin, 14: 595-600, 1966.
Song JH, Shon MS, Kim HO, Kim JS, Kim ES, Kim GN. Antioxidant activity of oil extracted from ginseng seed. Asian Journal of Beauty and Cosmetology, 12: 235-240, 2014.

Yeom MH, Lee JY, Kim JS, Park CW, Kim DH, Kim HK. The anti-aging effects of Korean ginseng berry in the skin. Korean Journal of Pharmacognosy, 41: 26-35, 2010. 


\section{국문초록}

\section{인삼열매 에탄올 추출물의 화장품 소재로서 항산화, 항염 효과}

김현숙, 고경숙*

원광대학교 뷰티디자인학과, 전라북도 익산시, 한국

목적: 본 연구는 인삼열매의 화장품 소재로서 활용가능성을 평가하기 위하여 에탄올 $70 \%$ 로 추출하여 실험을 진행하였다. 방법: 인 삼열매 에탄올 추출물을 GC/MS로 분석하였고, 총 폴리페놀, 플라보노이드 함량과 2,2-diphenyl-1-picrylhydrazyl (DPPH) 소거 활성을 통한 항산화, 세포 생존율(MTT assay) 확인을 통한 독성 평가를 하였다. 또한 nitric oxide (NO) 생성 저해 측정을 통해 항염 효과를 알아보았다. 결과: 총 폴리페놀 함량은 $152 \pm 12.4 \mu \mathrm{g} / \mathrm{mL}$, 총 플라보노이드는 $50.16 \pm 1.48 \mu \mathrm{g} / \mathrm{mL}$ 로 나타났다. DPPH 소 거활성은 추출물 농도 $0.25 \mathrm{mg} / \mathrm{mL}$ 에서 $59.21 \pm 4.20 \%, 0.5 \mathrm{mg} / \mathrm{mL}$ 에서 $69.27 \pm 2.38 \%, 1 \mathrm{mg} / \mathrm{mL}$ 에서 $89.30 \pm 1.25 \%$ 로 소거능이 증가함을 확인하였다. 세포 생존율 평가는 세포 생존율을 $0.125-1 \mathrm{mg} / \mathrm{mL}$ 의 농도범위까지 평가하였을 때, 최고 농도 $1 \mathrm{mg} / \mathrm{mL}$ 에 서 80.92 $\pm 5.77 \%$ 의 생존율을 확인하였다. LPS로 염증반응이 유도된 RAW 264.7 세포를 통해 nitric oxide (NO) 생성 저해효과 측 정에서는 추출물의 농도가 $0.25 \mathrm{mg} / \mathrm{mL}$ 일 때 $25.58 \pm 3.11 \mu \mathrm{M}, 0.5 \mathrm{mg} / \mathrm{mL}$ 일 때 $13.91 \pm 3.86 \mu \mathrm{M}, 1 \mathrm{mg} / \mathrm{mL}$ 일 때 $3.91 \pm 1.55$ $\mu \mathrm{M}$ 로 농도가 증가함에 따라 감소하여 항염 효과가 있음을 확인하였다. 결론: 인삼열매 에탄올 추출물은 항산화 및 항염 효과가 우 수하였으며, 천연 기능성 화장품 소재로서의 가능성이 있는 것으로 사료되었다.

핵심어: 인삼열매, 항산화, 항염, 폴리페놀, 화장품

\section{참고문헌}

고경숙. 자화지정 메탄올추출물의 항산화 효능에 관한연구. 한국미용학회지, 18: 1082-1086, 2012.

김건우, 최윤희, 김병록, 김영욱, 성락선, 한민희, 김경애, 최민주, 정용기. 새싹인삼과 차풀 복합추출물의 피부 항산화 및 미백효과. 아시안뷰티화장품학술지, 16: 309-320, 2018.

박종대. 고려인삼의 화학성분에 관한 고찰. Journal of Ginseng Research, 20: 389-415, 1996.

송지혜, 손명수, 김혜옥, 김종식, 김의수, 김교남. 인삼종자에서 추출한 오일의 항산화 활성. 아시안뷰티화장품학술지, 12 : 235-340, 2014.

염명훈, 이진영, 김지성, 박찬웅, 김덕희, 김한곤. 인삼열매의 피부노화 억제 효과. 생약학회지, 41: 26-30, 2010. 이가순, 김관후, 성봉재, 김선익, 한승호, 이석수, 양혜, 유영춘. 인삼열매추출물의 용매분획물이 LPS로 유도된 RAW264.7세포에 대한 항염활성. 한국약용작물학회지, 22: 449-456, 2014.

이세우, 최형일, 김애정, 한정순. 산양삼 분말을 첨가한 선식의 미용기능성 식품으로서의 응용 가능성. 아시안뷰티화장품 학술지, 16: 201-210, 2018.

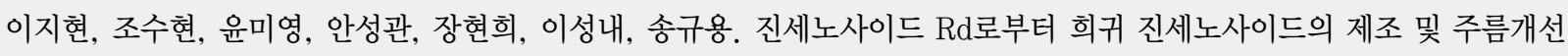
효과. 아시안뷰티화장품학술지, 13: 909-916, 2015.

전지민, 최성규, 김윤정, 장수진, 천종우, 이현상. 유산균 발효에 의한 인삼열매 추출물의 항산화 및 항노화 효과. 대한화 장품학회지, 37: 75-81, 2011.

황지우, 양영헌, 최태부. 화장품 소재로서 발아 귀치 추출물의 생리활성 특성. 아시안뷰티화장품학술지, 18: 137-148, 2020. 


\section{中文摘要}

\section{人参浆果乙醇提取物作为化妆品成分的抗氧化和抗炎作用}

金賢淑，高敬淑

圆光大学美容设计学科, 全罗北道益山市，韩国

目的: 评估人参浆果在化妆品中的适用性。方法: 采用气相色谱-质谱法（GC-MS）分析人参浆果乙醇提取物。 使用2,2-diphenyl-1-picrylhydrazyl (DPPH)消除能力以及测总多酚和类黄酮含量来确定抗氧化剂活性 ; 进行细 胞生存力（MTT分析）确认毒性，同时通过测量对一氧化氮（NO）产生的抑制作用来确认抗炎作用。结果：总 多酚和类黄酮含量分别为 $152 \pm 12.4 \mu \mathrm{g} / \mathrm{mL}$ 和 $50.16 \pm 1.48 \mu \mathrm{g} / \mathrm{mL}$ 。DPPH消除活性在浓度为 $0.25,0.5,1 \mathrm{mg} /$ $\mathrm{mL}$ 时，分别为 $59.21 \pm 4.20 \% ， 69.27 \pm 2.38 \% ， 89.30 \pm 1.25 \%$ 。0.125-1 mg/mL 浓度范围内测量细胞活力 时，显示在最大浓度 $1 \mathrm{mg} / \mathrm{mL}$ 时，存活率为 $80.92 \pm 5.77 \%$ 。在通过LPS诱导炎症反应的RAW 264.7细胞中产生 一氧化氮（NO）的抑制作用的测量中，浓度为 $0.25 ， 0.5,1 \mathrm{mg} / \mathrm{mL}$ 时， NO生成量分别为 $25.58 \pm 3.11 \mu \mathrm{M}$,

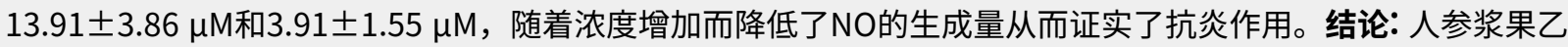
醇提取物具有优良的抗氧化和抗炎作用，可作为功能性美容原料。

关键词: 人参浆果，抗氧化剂，消炎，多酚，化妆品 
